\title{
Composition and Acaricidal Activities of Rosmarinus Officinalis Essential Oil against Tetranychus urticae and Its Predatory Mite Phytoseuilus persimilis
}

\author{
Hany K. Abd-Elhady ${ }^{1}$ and El-Zahi S. El-Zahi ${ }^{2}$
}

\begin{abstract}
Searching for pesticidal activity of plant extracts with some known medicinal attributes could lead to the discovery of new agents for pest control. The essential oil (EO) was extracted from aerial parts of Rosmarinus officinalis by hydrodistillation method and tested for its toxicity against adult females of two-spotted spider mite Tetranychus urticae Koch (Acari: Tetranychidae) and its predatory mite Phytoseuilus persimilis Athias-Henriot (Acari: Phytoseiidae) under laboratory conditions. Exposure periods were 24, 48, and $72 \mathrm{~h}$. The results indicated that adults of $T$. urticae were more susceptible to $\mathrm{EO}\left(\mathrm{LC}_{50}\right.$ ranged from 10.70 to $17.30 \mathrm{ml} / \mathrm{L}$ ) than $P$. persimilis $\left(\mathrm{LC}_{50}\right.$ ranged from 28.05 to $\left.42.09 \mathrm{ml} / \mathrm{L}\right)$. Laboratory bioassay results indicated that the EO caused high mortality of spider mites with high fumigant and repellent activities. EO with the highest used concentration (10\%) caused no phytotoxicity to some host plants of $T$. urticae (greenhouse-grown cotton, bean, tomato and cucumber). The chemical composition of hydrodistilled essential oil of $R$. officinalis was identified through GC/MS. The main constituents of the oil were 1,8-cineole (39.74\%), camphor $(22.76 \%)$, cis-ocimene $(\mathbf{8 . 8 9 \% )}$ and camphene $(\mathbf{7 . 0 1 \%})$ which may provide the acaricidal properties against $T$. urticae. Results of the present study suggested that Rosmarinus officinalis entiaessl oil could be useful in promoting new agents for mite control from the medicinal plants.
\end{abstract}

Key words: Rosmarinus officinalis, Essential oil, Acaricidal activity, Phytoseuilus persimilis, Tetranychus urticae, Chemical composition

\section{INTRODUCTION}

The two-spotted spider mite, Tetranychus urticae Koch (Acari: Tetranychidae) is one of the most serious pests in some of agricultural systems (Deligeorgidis et al., 2006, 2007). It ingests leaf cell contents, thus reduces plant photosynthesis (Park and Lee, 2002) and potentially decreases yield quality and quantity (Flaherty and Wilson, 1999). This pest is commonly controlled by applications of synthetic acaricides (Pontes et al., 2007a). The number of confirmed resistant mite species to synthetic pesticides has continued to rise, apart from risks associated with the use of these chemicals (Aslan et al., 2004). Unfortunately, spider mites have developed resistance to most available pesticides and the weakness of acaricidal efficacy is considered the

\footnotetext{
${ }^{1}$ Department of Pesticides, Faculty of Agriculture, Menoufiya

University, Shebin El-Kom 32511, Egypt.

${ }^{2}$ Department of Pesticides Testing, Plant Prot. Res. Inst.,

Dokki, Giza, Egypt.

Received August 9, 2011, Accepted September26, 2011
}

major problem encountered (Ay, 2005). The spider mite developed up to 100-fold resistance to dicofol and over 460-fold to parathion (Dagli and Tunc, 2001). As a result, the efficacy of many miticides has been reduced and the cost of chemical control has increased. Therefore, there is an urgent need to develop safer and efficient alternatives that have potential to replace synthetic pesticides and are convenient to use for control of $T$. urticae. Alternatives to conventional acaricides are needed, because many are being banned from the market. Essential oils of aromatic plants are considered as good control alternative tools. The search for efficient natural pesticide substances with low environmental toxicity has increased (Kabir et al., 2003; Silva et al., 2004). The essential oils of aromatic plants are among the most efficient pesticides of botanical origin and often constitute the bioactive fraction of plant extracts (Cosimi et al., 2009). Plant essential oils have a broad spectrum of activity against insects and mites due to their several modes of action, including repellent and antifeedant activities, inhibition of molting and respiration and reduction in growth and fecundity (Enan, 2001; Akhtar and Isman, 2004).

The predatory mite Phytoseiulus persimilis AthiasHenriot (Acari: Phytoseiidae) is well known as a predatory mite that specializes on the Tetranychid species, and it may considered a tool in the integrated pest management program for controlling spider mite $T$. urticae in many countries throughout the world (Cote $e t$ al., 2002; Kim and Yoo, 2002). Use of insecticides and natural enemies has become essential components of IPM in field and greenhouses (Yi et al., 2007). Essential oils derived from plants also may have minimal direct and/or indirect effects on natural enemies (Isman, 2006; Bostanian et al., 2005). They are more compatible with the environmental components than synthetic pesticides (Isman and Machial, 2006). Choi et al. 2004, tested a total of 53 essential oils against $T$. urticae and $P$. persimilis as a fumigant. Rosemary oil is relatively effective against mite also found to be toxic to the predaceous mites Amblyseius barkeri Hughes, A. zaheri and Typhlodromus athiasae Porath (Momen and Amer, 1999). The oils are generally composed of complex mixtures of monoterpenes, biogenetically related 
phenols, and sesquiterpenes. Examples include 1,8cineole, the major constituent of rosemary oil (Opender et al., 2008).

Rosemary (Rosmarius officinalis L.) is a woody, perennial herb native to the Mediterranean region. It is cultivated mainly in Mediterranean countries (Szumny et al., 2010). Rosemary, from family Labiatae, is an aromatic shrub with an intense pleasant smell reminiscent of pine wood. Rosemary oil has been traditionally used as a medicine for colic, nervous disorders and painful menstruation. Among bioactive natural compounds, several plant essential oils (Calmasur et al., 2006) were evaluated as acaricides. The insecticidal and larvicidal properties of rosemary essential oil are documented (Waliwitiya et al., 2009; Pavela, 2008). Natural products have been used as templates for semi-synthetic acaricidal agents (Tsukamoto et al., 1997a, b). Moving toward green chemistry processes and developing new crop protection tools with novel modes of action to control the twospotted spider mite are needed.

The aim of this work was (i) to evaluate the acaricidal activities of the EO of $R$. officinalis on the two-spotted spider mite $T$. urticae and its predatory mite $P$. persimilis . (ii) to determine the chemical composition of the $\mathrm{EO}$ of $R$. officinalis.

\section{MATERIALS AND METHODS}

\subsection{Plant material and extraction of the essential oil}

\subsection{Plant material}

Fresh aerial parts of $R$. officinalis were collected during its flowering period from the research farm of National Research Center (NRC), Dokki, Giza, Egypt in 2009 and shadow dried for 7-9 days at room temperature $\left(25 \pm 2^{\circ} \mathrm{C}\right)$. The $\mathrm{EO}$ of rosemary was extracted by hydro-distillation using a Clevenger-type apparatus for $3 \mathrm{~h}$ as described by Negahban et al., 2006. The oily layer obtained on top of the aqueous distillate was separated and dried with anhydrous sodium sulfate $(0.5 \mathrm{~g})$. The extracted EO was kept in sealed airtight glass vials and covered with aluminum foil at $5^{\circ} \mathrm{C}$ until further analysis.

\subsection{GC/MS analysis of the essential oil}

Major constituents of the essential oil were identified by gas chromatography/mass spectrometry (GC/MS) using a Shimadzu GC-17A gas chromatograph (Shimadzu Corp., Kyoto, Japan), coupled with a Shimadzu mass spectrometer detector (GC-MS QP5050A). The GC-MS system was equipped with a TRACSIL Meta X5 column (Teknokroma S. Coop. C. Ltd., Barcelona, Spain; $30 \mathrm{~m} \times 0.25 \mathrm{~mm}$ i.d., $0.25 \mu \mathrm{m}$ film thickness). Analyses were carried out using helium as carrier gas at a flow rate of $1.0 \mathrm{~mL} / \mathrm{min}$ at a split ratio of $1: 10$ and the following temperature program: $40^{\circ} \mathrm{C}$ for $5 \mathrm{~min}$; rising at $3.0^{\circ} \mathrm{C} / \mathrm{min}$ to $200^{\circ} \mathrm{C}$ and held for $1 \mathrm{~min}$; rising at $15^{\circ} \mathrm{C} / \mathrm{min}$ to $280^{\circ} \mathrm{C}$ and held for $10 \mathrm{~min}$. The injector and detector were held at 250 and $300^{\circ} \mathrm{C}$, respectively. Diluted samples (1:10 pentane, v/v) of 0.2 $\mu \mathrm{L}$ of the extracts were always injected. Mass spectra were obtained by electron ionization at $70 \mathrm{eV}$, using a spectral range of $\mathrm{m} / \mathrm{z} 45-450$. The identification of individual compounds of essential oils was accomplished using two different analytical methods: (a) $\mathrm{KI}$, Kovats indices in reference to $n$-alkanes $\left(\mathrm{C}_{8}-\mathrm{C}_{32}\right)$ by National Institute of Standards and Technology (NIST) 2009; and (b) mass spectra (authentic chemicals and Wiley spectral library collection). Identification was considered to be tentative when it was based on mass spectral data only. The relative concentration of each component of the essential oil was quantified according to the peak area integrated by the analysis program.

\subsection{Acaricidal activity}

\subsubsection{Origin and rearing of mites}

Field strains of mites were established from field collections of spider mite $T$. urticae and $P$. persimilis from cotton plantations at the farm of Sakha Agricultural Research Station, Egypt. Mite cultures were maintained in climatic rooms at $27 \pm 1^{\circ} \mathrm{C}$ and $60 \pm 5 \%$ R.H., with $16 \mathrm{~h} \mathrm{~L}: 8 \mathrm{hD}$ photoperiod for two generations to increase the cultures populations. Spider mites were reared on bean plants (Phaseolus vulgaris L.), a more suitable host using Dittrich (1962) technique. The predacious mite $P$. persimilis was reared in plastic boxes $(22 \times 15 \times 10 \mathrm{~cm})$; a cotton pad was put in the middle of each box, provided with water as a barrier to prevent predatory mite individuals from escaping. Predatory mites were provided with highly infested bean leaves (mixed prey stages) three times per week.

\subsubsection{Toxicity tests}

$\mathbf{L C}_{\mathbf{5 0}}$ for adult females of $\boldsymbol{T}$. urticae: Leaves of bean plants, $P$. vulgaris L., were punched for preparing leaf discs $(3.0 \mathrm{~cm}$ diameter). Leaf discs were placed on wet cotton pads in Petri dishes (12 cm diameter). Seven concentrations (i.e. 2.5, 5.0 10.0, 20.0, 40.0, 80.0 and $100.0 \mathrm{ml} / \mathrm{L}$ ) of EO each with nine replicates were prepared using tap water plus the spreader (Tween 20, $0.5 \%)$. Tested concentrations of the EO were sprayed on leaf discs with aid of hand sprayer even complete coverage. Control treatments were made using tap water and the spreader only. After drying of leaf discs at room temperature, ten adult females of $T$. urticae were transferred to the lower surface of each treated leaf disc. Mortality percentages were calculated after 24, 48 and $72 \mathrm{~h}$ from exposing T. urticae individuals to treated leaf discs. T. urticae adults were considered dead if they 
looked black and no movement was observed when probing with the tip of fine haired brush.

$\mathbf{L C}_{50}$ for adult females of $\boldsymbol{P}$. persimilis: Four adult females of predacious mite were transferred to each bean leaf disc ( $3 \mathrm{~cm}$ diameter) previously infested with 30 individuals of $T$. urticae and places on moistened cotton pad in a Petri dish (12 cm diameter). The leaf discs were sprayed as previously mentioned with the same concentrations and replicates. Mortality of predatory mites was recorded 24,48 and $72 \mathrm{~h}$ after treatments.

Repellent activity: To study the preference response of T. urticae when given a choice between EO-treated and untreated plants, the deterrent activity of rosemary oil at concentrations of $0.25,0.50,1.00$ and $1.50 \%$ against $T$. urticae was assessed. Bean leaves were cut into discs $(3.0 \mathrm{~cm}$ diameter) of symmetrical portion along the midrib obtained per each disc. Half of each disc was sprayed with the EO tested concentration, with aid of hand sprayer even complete coverage, while the other half was sprayed with water plus the spreader (Tween $20,0.5 \%)$ as check. The treated discs were left to dry and put on moistened cotton wool in Petri dishes (10.0 $\mathrm{cm}$ diameter). Twenty adult females were transferred on the midrib of each disc. Three discs were used as replicates for each concentration. The mites were left to move freely across the two portions of the disc. $T$. urticae individuals in each portion were counted after 12, 24 and $48 \mathrm{~h}$. The number of eggs laid on both sides was recorded after $48 \mathrm{~h}$. The deterrence index (DI) was calculated according to Pascual and Robledo, 1998 using the equation:

$\mathrm{DI}=[(\mathrm{C}-\mathrm{T}) /(\mathrm{C}+\mathrm{T})] \mathrm{x} 100$

Where: $\mathrm{T}$ and $\mathrm{C}$ represent the mean number of adult female on the treated and untreated portions of leaf disc, respectively.

Fumigant activity: The method used to evaluate the fumigant activity of the oil was adapted from Aslan et al. (2004). Glass jars receptacles with a capacity of 3.0 $\mathrm{L}$ were used as test chambers. One Petri dish $(7.5 \mathrm{~cm}$ diameter) was introduced to each chamber. Thirty adult females of $T$. urticae, 10 mites in each leaf disc $(2.5 \mathrm{~cm}$ diameter) of bean, were put in each Petri dish. Six discs were used as replicates for each concentration. Filter paper discs saturated with water were used under the leaf discs. Essential oil at 0.25, 0.50, 1.00, 2.00, 3.00, 4.00 and $5.00 \mathrm{ml}$ were applied on Whatman filter paper pieces $(2 \mathrm{~cm} \times 3 \mathrm{~cm})$, and fixed on the inner surface of the glass chambers, which corresponding to $0.08,0.17$, $0.33,0.67,1.00,1.33$ and $1.67 \mathrm{ml}$ oil $/ \mathrm{L}$ of air, respectively. No material was applied to the control glass chamber. The treatments were kept in a holding chamber of $27 \pm 1^{\circ} \mathrm{C}$ and $60 \pm 5 \%$ R.H., with $16 \mathrm{hL}: 8$ $\mathrm{hD}$ photoperiod. Exposure periods were 24, 48 and $72 \mathrm{~h}$ and the numbers of dead adults were counted.

\subsection{Phytotoxic effects}

The foliages of greenhouse-grown cotton, bean, tomato and cucumber, which represent some host plants of $T$. urticae, with four weeks old were visually examined to discover any phytotoxic effects after treatment with the essential oil. The highest concentration of the essential oil used in the experiments $(10 \%)$ was dissolved in water plus the spreader (Tween $20,0.5 \%$ ) and sprayed uniformly with a hand sprayer on the surface of whole host plant leaves $(10 \mathrm{ml}$ for each plant). Each plant in control groups was sprayed uniformly with $10 \mathrm{ml}$ of water plus the spreader (Tween $20,0.5 \%$ ) solution. The differences in the appearance of treated plants compared with controls were considered as indication of phytotoxicity.

\subsection{Data analysis}

The mortality percentage was corrected using Abbott's formula 1925; the observed data were then analyzed by probit analysis PC (Finney, 1971). Means of $T$. urticaet or $P$. persimilis predatory mite numbers among treatments were calculated and compared with a single factor analysis of variance (ANOVA). Duncan's multiple range test was used to determine significant differences $(p<0.05)$ between treatments by CoStat system for Windows, version 6.311, CoStat Program (2006), Berkeley,CA, USA).

\section{RESULTS AND DISCUSSION}

\subsection{Essential oil constituents}

The hydrodistillaton of the dried aerial parts of $R$. officinalis gave EO with yield of $1.2 \%$ (w/w). GC/MS analysis indicated that there are thirty-one compounds, representing $99.00 \%$ of the essential oil. Their retention indices and percentage composition, listed in order of elution in the column, are given in Table (1). It is obvious from data in this Table that the major components of $R$. officinalis essential oil were identified as 1,8 -cineole $(39.74 \%)$, camphor $(22.76 \%)$, cisocimene $(8.89 \%)$ and camphene $(7.01 \%)$. The essential oil of $R$. officinalis was rich in some monoterpenoids which may provide the acaricidal properties of this oil against $T$. urticae. Like other essential oils, natural rosemary oil is a complex mixture of monoterpenoids. Considering that target site resistance is an important problem for mite control, it is more probable that mites will evolve resistance faster to an acaricide based on a single active ingredient than to one based on a mixture of different active compounds as $R$. officinalis essential oil (EO) used in this study. The major compounds found in the essential oil have previously been reported 
Table 1. Chemical composition of essential oil isolated by hydrodistillation from aerial parts of Rosmarinus officinalis analyzed by GC/MS

\begin{tabular}{|c|c|c|c|}
\hline Number & $\mathbf{R I}^{a}$ & Compound $^{b}$ & ${\text { Peak Area }(\%)^{c}}^{c}$ \\
\hline 1 & 9.068 & alpha pinene & 0.15 \\
\hline 2 & 9.319 & Cis-ocimene & 8.89 \\
\hline 3 & 9.790 & alpha-fenchene & 0.47 \\
\hline 4 & 9.873 & camphene & 7.01 \\
\hline 5 & 10.430 & sabinene & 0.11 \\
\hline 6 & 10.714 & beta-pinene & 3.32 \\
\hline 7 & 11.801 & isocineol & 0.15 \\
\hline 8 & 12.176 & para cymene & 2.68 \\
\hline 9 & 12.353 & 1-limonene & 1.64 \\
\hline 10 & 12.638 & 1,8-cineole & 39.74 \\
\hline 11 & 13.908 & linalool oxide & 0.25 \\
\hline 12 & 14.890 & alpha-terpinolene & 0.58 \\
\hline 13 & 16.366 & alpha-campholene aldehyde & 0.39 \\
\hline 14 & 17.557 & camphor & 22.76 \\
\hline 15 & 18.115 & pinocarvone & 0.46 \\
\hline 16 & 18.322 & alpha-terpineol & 0.40 \\
\hline 17 & 18.813 & terpineol & 0.32 \\
\hline 18 & 19.012 & p-cymen-8-ol & 0.19 \\
\hline 19 & 19.428 & alpha-terpineol & 0.91 \\
\hline 20 & 19.633 & myrtenal & 0.28 \\
\hline 21 & 20.190 & verbenone & 0.40 \\
\hline 22 & 21.736 & carvone & 0.16 \\
\hline 23 & 22.335 & cis sabinene hydrate & 0.16 \\
\hline 24 & 23.549 & bornyl acetate & 1.34 \\
\hline 25 & 23.720 & isobornyl acetate & 0.63 \\
\hline 26 & 24.310 & trans-caryophyllene & 0.79 \\
\hline 27 & 24.726 & trans -verbeol & 1.90 \\
\hline 28 & 25.243 & myrtenol & 1.19 \\
\hline 29 & 32.426 & germacrene D & 0.10 \\
\hline 30 & 37.450 & caryophyllene oxide & 1.42 \\
\hline \multirow[t]{2}{*}{31} & 38.618 & humuladienone & 0.21 \\
\hline & & Total & 99.00 \\
\hline
\end{tabular}

${ }^{a}$ RI, retention index on a TRACSIL Meta X5 column

${ }^{b}$ Compounds are listed into order of their elution from a TRACSIL Meta X5 column

${ }^{c}$ Compound percentag

to have activity against a variety of insects, mites, weeds and plant pathogens (Bakkali et al., 2008; Koschier, 2008). Individual activities of eight monoterpenoids (anethole, carvacrol, 1,8-cineole, p-cymene, menthol, gamma-terpinen, terpinen-4-ol and thymol) were investigated against three major greenhouse pests, i.e. females and eggs of the carmine spider mite, females of the cotton aphid Aphis gossypii and second instar larvae of the western flower thrips Frankliniella occidentalis (Erler and Tunc, 2005). The composition of $R$. officinalis essential oil obtained in this study was similar to that one characterized by Miresmailli et al. (2006), with 1,8-cineole and camphor as major compounds.

\subsection{Acaricidal activity}

Toxic effects:

The $\mathrm{LC}_{50}$ values of rosemary EO along with their confidence limits (CL) and slope values against adult females of $T$. urticae and adult females of $P$. persimilis after 24, 48 and 72 hours exposure periods were listed in Table (2). It is clear that adult females of $T$. urticae were more susceptible to $\mathrm{EO}\left(\mathrm{LC}_{50}\right.$ ranged from 10.70 to $17.30 \mathrm{ml} / \mathrm{L}$ ) than adult females of $P$. persimilis $\left(\mathrm{LC}_{50}\right.$ ranged from 28.05 to $42.09 \mathrm{ml} / \mathrm{L}$ ). With exposure period increase ,the acaricidal activity of EO against adult females of $T$. urticae increased with significant 
differences $\left(\mathrm{LC}_{50}\right.$ values were 10.70 and $17.30 \mathrm{ml} / \mathrm{L}$ after exposure of 72 and 24 hours, respectively.) and the same results obtained in case of adult females of $P$. persimilis.

Our results clearly confirmed that essential oil from $R$. officinalis posses acaricidal activity against the $T$. urticae adults under laboratory conditions. Pontes et al. ( 2007b) reported that plant essential oils have been found to be active against $T$. urticae . Plant extracts contain compounds that show ovicidal, repellent, antifeedant, sterilant and toxic effects in insects (Isman, 2006; Bakkali et al., 2008). The toxicity may be by contact, ingestion or through fumigant action. Plant essential oils and their constituents invariably have higher boiling points and such plant products that show insect toxicity in the vapour state have been recently reviewed by Rajendran and Sriranjini (2008). Although some studies have demonstrated the contact or volatile efficacy of essential oils against different mite species of the family Tetranychidae, chronic exposure to rosemary oil in high concentration has caused contact dermatitis in some rare cases (Cockayne and Gawkrodger, 1997; Hjorther et al., 1997).

\section{Repellent activity:}

The deterrence index (DI) of the EO at $0.25,0.50$, 1.00 and $1.50 \%$ on the adult females of T. urticae after 12, 24 and 48 hours of exposure, and average number of eggs laid per adult female on treated and untreated (control) leaves after $48 \mathrm{~h}$. exposure were listed in Table(3). It is intelligible that, adult females of $T$. urticae preferred the untreated section of the leaves to feed and deposit eggs. After $12 \mathrm{~h}$ of exposure, few numbers of $T$. urticae adult females were recorded on leaves treated sections with essential oil concentrations. The higher concentrations of the oil used revealed a higher repellent effect on adult females of $T$. utricae. Females of the mite showed an ovipostion preference for residue-free substrate where the mean number of eggs laid on the water treated control halves of the leaf discs were higher (8.4) than that on the EO treated halves (1.1), at the higher used concentration $(1.50 \%)$.

Table 2. Toxicity of extracted essential oil from Rosmarinus officinalis to adult females of Tetranychus urticae and its predatory mite Phytoseuilus persimilis

\begin{tabular}{ccccc}
\hline Mite sp. & $\begin{array}{c}\text { Exposure } \\
\text { period(h) }\end{array}$ & $\mathbf{L C}_{\mathbf{5 0}}{ }^{*}(\mathbf{m l} / \mathbf{L})$ & $\mathbf{9 5 \%} \mathbf{C L}$ & Slope $\pm \mathbf{S E}$ \\
\hline \multirow{3}{*}{ T.urticae } & 24 & $17.30^{\mathrm{b}}$ & $(13.24-20.58)$ & $0.9006 \pm 0.0955$ \\
\cline { 2 - 5 } & 48 & $12.23^{\mathrm{ab}}$ & $(9.83-15.83)$ & $1.1092 \pm 0.0987$ \\
\hline \multirow{3}{*}{$\boldsymbol{P}$. persimilis } & 72 & $10.70^{\mathrm{a}}$ & $(8.62-13.14)$ & $1.1293 \pm 0.0988$ \\
\cline { 2 - 5 } & 24 & $42.09^{\mathrm{c}}$ & $(33.15-57.03)$ & $1.4321 \pm 0.2001$ \\
\cline { 2 - 5 } & 48 & $31.43^{\mathrm{c}}$ & $(24.15-40.71)$ & $1.5373 \pm 0.2061$ \\
\hline
\end{tabular}

${ }^{*} \mathrm{LC}_{50}$ values followed by the same letter within each vertical column are not significantly different (95\% CL do not overlap).

Table 3. Repellent effect of extracted essential oil from Rosmarinus officinalis on adult females of Tetranychus urticae

\begin{tabular}{|c|c|c|c|c|}
\hline \multirow{2}{*}{$\begin{array}{l}\text { Exposure } \\
\text { Period (h) }\end{array}$} & \multirow{2}{*}{$\begin{array}{c}\text { Oil Concentration } \\
(\%)\end{array}$} & \multirow{2}{*}{$\begin{array}{l}\text { Deterrence } \\
\text { Index (DI) }\end{array}$} & \multicolumn{2}{|c|}{$\begin{array}{c}\text { Average number of } \\
\text { eggs }\end{array}$} \\
\hline & & & Treatment & Control \\
\hline \multirow{4}{*}{12} & 0.25 & 50.00 & n.d. & n.d. \\
\hline & 0.50 & 55.56 & n.d. & n.d. \\
\hline & 1.00 & 61.11 & n.d. & n.d. \\
\hline & 1.50 & 66.67 & n.d. & n.d. \\
\hline \multirow{4}{*}{24} & 0.25 & 72.22 & n.d. & n.d. \\
\hline & 0.50 & 77.78 & n.d. & n.d. \\
\hline & 1.00 & 88.98 & n.d. & n.d. \\
\hline & 1.50 & 94.44 & n.d. & n.d. \\
\hline \multirow{4}{*}{48} & 0.25 & 72.22 & $3.0^{\mathrm{c}}$ & $5.2^{\mathrm{a}}$ \\
\hline & 0.50 & 77.78 & $2.1^{\mathrm{b}}$ & $6.4^{\mathrm{b}}$ \\
\hline & 1.00 & 83.83 & $1.8^{\mathrm{b}}$ & $6.3^{\mathrm{b}}$ \\
\hline & 1.50 & 83.83 & $1.1^{\mathrm{a}}$ & $8.4^{\mathrm{c}}$ \\
\hline
\end{tabular}

Values followed by the same letter within each column are not significantly different, n.d., not determined. 
Table 4. Fumigant effect of extracted essential oil from Rosmarinus officinalis against adult females of Tetranychus urticae

\begin{tabular}{cccc}
\hline Exposure period (h) & $\mathbf{L D}_{\mathbf{5 0}}{ }^{*}(\mathbf{m l} / \mathbf{L})$ & $\mathbf{9 5 \%} \mathbf{C L}$ & Regression equation \\
\hline $\mathbf{2 4}$ & $1.0615^{\text {a }}$ & $(0.6794-2.2908)$ & $\mathrm{Y}=4.965+1.338 \mathrm{X}$ \\
\hline $\mathbf{4 8}$ & $0.8563^{\text {a }}$ & $(0.5605-1.5592)$ & $\mathrm{Y}=5.101+1.497 \mathrm{X}$ \\
\hline $\mathbf{7 2}$ & $0.6646^{\mathrm{a}}$ & $(0.4036-1.1823)$ & $\mathrm{Y}=5.290+1.632 \mathrm{X}$ \\
\hline
\end{tabular}

$\mathrm{LD}_{50}$ values followed by the same letter within each column are not significantly different (95\% CL do not overlap).

The obtained results agreed with that of Park et al.( 2005) and Trongtokit et al.(2005).they stated that a number of EO showed repellent effect against mosquitoes and usually attributed to their main compounds. A concentration of $12.5 \%$ of $R$. officinalis showed the longest repellency time for mosquitoes (Gillij et al., 2008). Comparisons of the principal components of $R$. officinalis suggest that camphor was the main component responsible for the repellent effects (Gillij et al., 2008).

\section{Fumigant effect:}

The $\mathrm{LD}_{50}$ values, $95 \%$ confidence limits and the regression line equations are shown in Table (4). It is clear that , the $\mathrm{LD}_{50}$ values were calculated as 1.0615 , 0.8563 and $0.6646 \mathrm{ml} / \mathrm{L}$ of air with $95 \%$ confidence limits from 0.6794 to 2.2908 , from 0.5605 to 1.5592 and from 0.4036 to $1.1823 \mathrm{ml} / \mathrm{L}$ of air after 24,48 and $72 \mathrm{~h}$ of treatment, respectively. With the increase of exposure periods, the fumigant effect of the essential oil from $R$. officinalis against adult females of $T$. urticae increased. Our results coincided with Isman, 2000 when reported that, the aromatic vapor of rosemary affected the two-spotted spider mite as a fumigant. Koschier and Sedy, (2001) studied the antifeedant effect of rosemary essential oil against onion thrips. Several reports indicated that monoterpenoids caused insect mortality by inhibiting acetylcholinesterase enzyme activity (Houghton et al., 2006). In this aspect, acaricidal activities of the essential oil used in our study on adult mortalities could be due to the fumigant toxicities of the major components of the essential oil. The effect of the essential oils on aphid mortality was attributed primarily to starvation or oral and fumigant toxicity (Hori, 1999).

\subsection{Phytotoxic effects:}

The foliages of greenhouse - grown cotton, bean, tomato and cucumber with four weeks old, which represent some host plant species of $T$. urticae, were visually examined to discover any changes in the growth of these host plants after treatment with the highest used concentration (10\%) of the essential oil in the present study. No phytotoxic effects of the essential oil were observed on treated plants comparing with untreated plants. In a few cases, essential oil-treated plants have become attractive to plant-damaging insects and phytotoxic effects on some cultivated plants have been observed (Miresmailli and Isman, 2006). Ibrahim et al. (2001) reported the phytotoxic effects in limonenetreated plants, whereas Chiasson et al. (2004) did not observe any phytotoxicity among lettuce, roses, and tomatoes that were treated with a Chenopodium-based pesticide.

\section{CONCLUSION}

The obtained results suggested that the essential oil have the potential for use in the control of T. urticae. In accordance with the present conclusions, $R$. officinalis essential oil may be used as ecologically safe alternative miticides against $T$. urticae, and its content could lead to the development of new classes of miticidal compounds. However, further studies are needed to evaluate the mode of action and cost-efficacy of this EO on wide range of pests. Natural miticides are a desirable alternative to synthetic miticides because they have little environmental effect. In addition, no phytotoxic effects of rosemary oil to foliage of cotton, bean, tomato and cucumber, as host plants, have been observed with the highest tested concentration.

\section{REFERENCES}

Abbott, W. S. 1925. A method for computing the effectiveness of an insecticide. J. Econ. Entomol. 18: 265-267.

Akhtar, Y.and M.B.Isman, 2004. Comparative growth inhibitory and antifeedant effects of plant extracts and pure allelochemicals on four phytophagous insect species. J. Appl. Entomol. 128, 32-38.

Aslan, I.; H. Ozbek; O. Calmasur and F. Sahin, 2004. Toxicity of essential oil vapours to two greenhouse pests, Tetranychus urticae Koch and Bemisia tabaci Genn. Ind. Crops Prod. 19, 167-173.

Ay, R. 2005. Determination of susceptibility and resistance of some greenhouse populations of Tetranychus urticae Koch to chlorpyrifos (Dursban 4) by the Petri dish-Potter tower method. J. Pest Sci. 78: 139 - 143.

Bakkali, F.; S. Averbeck; D. Averbeck and M. Waomar, 2008. Biological effects of essential oils-a review. Food Chem. Toxicol. 46: 446-475.

Bostanian, N.J.; M. Akalach; and H. Chiasson, 2005. Effects of a Chenopodium-based botanical insecticide/acaricide on Orius insidiosus (Hemiptera: Anthocoridae) and Aphidius colemanii (Hymenoptera: Braconidae). Pest. Manag. Sci. 61, 979-984. 
Calmasur, O.; I. Aslan and F. Sahin, 2006. Insecticidal and acaricidal effect of three Lamiaceae plant essential oils against Tetranychus urticae Koch and Bemisia tabaci Genn. Ind. Crops Prod. 23: 140-146.

Chiasson, H.; N. J. Bostanian and C. Vicent, 2004. Acaricidal properties of a Chenopodium-based botanical. J. Econ. Entomol. 97: 1373-1377.

Choi, W. I.; S. G. Lee; H. M. Park and Y. J. Ahn, 2004. Toxicity of plant essential oils to Tetranychus urticae (Acari: Tetranychidae) and Phytoseiulus persimilis (Acari: Phytoseiidae). J. Econ. Entomol. 97: 553- 558.

Cockayne, S.E. and D.J. Gawkrodger, 1997. Occupational contact dermatitis in an aromatherapist. Contact Dermatitis 37:306-309.

Cosimi, S.; E. Rossi; P.L. Cioni and A. Canale, 2009. Bioactivity and qualitative analysis of some essential oils from Mediterranean plants against stored-product pests: Evaluation of repellency against Sitophilus zeamais Motschulsky, Cryptolestes ferrugineus (Stephens) and Tenebrio molitor (L.). Journal of Stored Products Research, 45, 125-132.

CoStat Program. 2006. Version 6.311, Cohort Software Inc, Monterey http://www.cohort.com/DownloadCoStat.html

Cote, K. W.; E. E. Lewis and P. Schultz, 2002. Compatibility of acaricide residues with Phytoseiulus persimilis and their effect on Tetranychus urticae. Hort Sci. 37: 906-909.

Dagli, F.and I. Tunc, 2001.Dicofol resistance in Tetranychus cinnabarinus: resistance and stability of resistance in populations from Antalya, Turkey. Pest. Manag. Sci. 57, 609-614.

Deligeorgidis, P.N.; C.G. Ipsilandis; G. Kaltsoudas; G. Sidiropoulos; N.P. Deligeorgidis; M. Vaiopoulou and A. Vardiabasis, 2007. Chemical control of Thrips tabaci, Epitrix hirtipennis and Myzus persicae in tobacco fields in Northern Greece.J. Entomol., 4: 463-468.

Deligeorgidis, P.N.; L. Giakalis; G. Sidiropoulos; M. Vaiopoulou; G. Kaltsoudas and C.G. Ipsilandis, 2006. Longevity and reproduction of Frankliniella occidentalis and Thrips tabaci on cucumber under controlled conditions. J. Entomol., 3: 61-69.

Dittrich, V., 1962. Acomparative study of toxicological test methods on population of the two-spotted spider mite $(T$. urticae) J. Econ. Entomol. 55: 644-648.

Enan, E., 2001. Insecticidal activity of essential oils: octopaminergic sites of action. Comp. Biochem. Physiol. C 130, 325-337

Erler, F.and I. Tunc, 2005. Monoterpenoids as fumigants against greenhouse pests: toxic, development and reproduction-inhibiting effects. Z. Pflanzenk. Pflanzen. 112, 181-192.

Finney, D.J., 1971. Probit Analysis, 3rd ed. Cambridge University press, Cambridge University, Press, London, UK.
Flaherty, D.L. and L.T. Wilson, 1999. Biological control of insects and mites on grapes. In: Bellows, T.S., Fisher, T.W. (Eds.), Handbook of Biological Control. Academic Press, New York, USA, pp. 853-869.

Gillij, Y.G.; R.M. Gleiser and J.A. Zygadlo, 2008. Mosquito repellent activity of essential oils of aromatic plants growing in Argentina. Bioresource Technology 99: 25072515.

Hjorther, A.B.; C. Christophersen; B.M. Hausen and T. Menne, 1997. Occupational allergic contact dermatitis from carnosol, a naturally-occurring compound present in rosemary. Contact Dermatitis 37:99-100.

Hori, M., 1999. Antifeeding, settling inhibitory and toxic activities of labiate essential oils against the green peach aphid, Myzus persicae (Sulzer) (Homoptera: Aphididae). Appl. Entomol. Zool. 34: 113-118

Houghton, P.J.; Y. Ren and M.J. Howes, 2006. Acetylcholinesterase inhibitors from plants and fungi. Nat. Prod. Rep. 23: 181-199.

Ibrahim, M. A.; P. Kainulainen; A. Aflatuni; K. Tiilikkala and J. K. Holopainen, 2001. Insecticidal, repellent, antimicrobial activity and phytotoxicity of essential oils: with special reference to limonene and its suitability for control of insect pests. Agric. Food Sci. Finl. 10: 243-259.

Isman, M.B., 2000. Plant essential oils for pest and disease management. Crop Prot.19: 603-608.

Isman, M.B., 2006. Botanical insecticides, deterrents, and repellents in modern agriculture and an increasingly regulated world. Annu. Rev. Entomol. 51, 45-66.

Isman, M.B. and C.M. Machial, 2006. Pesticides based on plant essential oils: from traditional practice to commercialization. In M. Rai and M.C. Carpinella (eds.), Naturally Occurring Bioactive Compounds, Elsevier, BV, pp 29-44.

Kabir, K.E.; A.R. Khan and M.A. Mosaddik, 2003. Goniothalamin - a potent mosquito larvicide from Bryonopsis laciniosa L. J. Appl. Entomol. 127: 112-115.

Kim S.S. and S.S. Yoo, 2002. Comparative toxicity of some acaricides to the predatory mite, Phytoseiulus persimilis and the two-spotted spider mite Tetranychus urticae. Bio Control, 47: 563-573.

Koschier, E.H., 2008. Essential oil compounds for thrips control-a review. Nat. Prod. Commun. 3: 1171-1182.

Koschier, E.L. and K.A. Sedy, 2001. Effects of plant volatiles on the feeding and oviposition of Thrips tabaci. In $\mathrm{R}$. Marullo and L. Mound (eds.), Thrips and Tospoviruses, CSIRO, Australia, pp. 185-187.

Miresmailli S.; R. Bradbury and B. I. Murray, 2006. Comparative toxicity of Rosmarinus officinalis L. essential oil and blends of its major constituents against Tetranychus urticae Koch (Acari: Tetranychidae) on two different host plants. Pest Manag. Sci. 62:366-371.

Miresmailli, S. and M.B. Isman, 2006. Efficacy and Persistence of Rosemary Oil as an Acaricide Against Twospotted Spider Mite (Acari: Tetranychidae) on Greenhouse Tomato. J. Econ. Entomol. 99(6): 2015-2023. 
Momen, F.M. and S.A. Amer, 1999. Effect of rosemary and sweet arjoram on three predacious mites of the family Phytoseiidae (Acari: Phytoseiidae). Acta Phytopathologica Entomologica Hungarica, 34: 355-361.

National Institute of Standards and Technology (NIST); http://webbook.nist.gov/chemistry/name-ser.html (accessed Dec 2009).

Negahban, M.; S. Moharramipour and F. Sefidkon, 2006. Insecticidal activity and chemical composition of Artemisia sieberi Besser oil from Karaj, Iran. J. AsiaPacific Entomol. 9: 61-66.

Opender, K.; W. Suresh and G.S. Dhaliwal, 2008. Essential Oils as Green Pesticides: Potential and Constraints. Biopesticides International. 4: 63-84.

Park, B.S.; W.S. Choi; J.H. Kim and S.E. Lee, 2005. Monoterpenes from thyme (Thymus vulgaris) as potential mosquito repellents. J. Am. Mosq. Contr. Assoc. 21, 80 83.

Park, Y.L. and J.H. Lee, 2002. Leaf cell and tissue damage of cucumber caused by two-spotted spider mite (Acari: Tetranychidae). J. Econ. Entomol. 95; 952-957.

Pascual, V.M.J.and A. Robledo, 1998. Screening for antiinsect activity in Mediterranean plants. Ind. Crop. Prod. 8: 183-194.

Pavela, R., 2008. Insecticidal properties of several essential oils on the house fly(Musca domestica L.). Phytother. Res. 22, 274-278.

Pontes, W.J.T.; J.C.S. Oliveira; C.A.G. Camara; A.C. Lopes; M.G.C. Gondim; J.V. Oliveira and M.O. Schwartz, 2007a. Composition and acaricidal activity of the resin's essential oil of Protium bahianum Daly against two spotted spider mite (Tetranychus urticae). J. Essent. Oil Res. 19: 379383.

Pontes, W.J.T.; J.C.S. Oliveira; C.A.G. Camara; M.G.C. Gondim; J.V. Oliveira and M.O.E. Schwartz, 2007b. Acaricidal activity of the essential oils of leaves and fruits of Xylopia sericea St. Hill. On the two spotted spider mite (Tetranychus urticae Koch). Quim. Nova 30: 838-841.
Rajendran, S. and V. Sriranjini, 2008. Plant products as fumigants for stored-product insect control. J. Stored Prod. Res. 44, 126-135.

Roe, F.J., 1965. Chronic toxicity of essential oils and certain other products of natural origin. Food Cosmet. Toxicol. 33:311-324.

Silva, O.S.; P.R.T. Romao; R.D. Blazius and J.S. Prohiro, 2004. The use of andiroba Carapa guianensis as larvicide against Aedes albopictus. J. Am. Mosquito Contr. Assoc. 20: 456-457.

Szumny, A.; A. Figiel; A. Gutierrez-Ortiz, and A.A.CarbonellBarrachin, 2010. Composition of rosemary essential oil (Rosmarinus officinalis) as affected by drying method. Journal of Food Engineering, 97, 253-260.

Trongtokit, Y.; Y. Rrongsriyam; N. Komalamisra and C.H. Apiwathnasorn, 2005. Comparative repellency of 38 essential oils against mosquito bites. Phytother. Res. 19, 303-309.

Tsukamoto, Y.; H. Kajino; K. Sato; K. Tanaka and T. Yanai, 1997a. Synthesis of 24asubstituted milbemycin A(4) derivatives and their acaricidal activity against Tetranychus urticae. Biosci. Biotech. Biochem. 61: 806812.

Tsukamoto, Y.; H. Nakagawa; H. Kajino; K. Sato; K. Tanaka and T. Yanai, 1997b. Synthesis of novel 25-substituted milbemycin A(4) derivatives and their acaricidal activity against Tetranychus urticae. Biosci. Biotech. Biochem. 61: 1650-1657.

Waliwitiya, R.; C.J. Kennedy and C.A. Lowenberger., 2009. Larvicidal and oviposition-altering activity of monoterpenoids, trans-anethole and rosemary oil to the yellow fever mosquito Aedes aegypti (Diptera: Culicidae). Pest Manage. Sci. 65: 241-248.

Yi, C.; M. Kwon; T. T. Hieu; Y. Jang and Y. Ahn, 2007. Fumigant toxicity of plant Essential oils to Plutella xylostella (Lepidoptera: Yponomeutidae) and Cotesia glomerata (Hymenoptera: Braconidae), J. Asia-Pacific Entomol. Vol. 10: 157-163. 


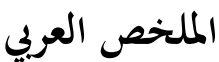

التركيب الكيميائي والنشاط الابادي للزيت الأساسي لإكليل الجبل المصري ضد أكاروس العنكبوت الأحمر ذو البقعتين Tetranychus urtica ومفترسه الأكاروسي

\section{Phytoseuilus persimilis}

هاني كمال عبد المادي، الزاهي صابر الزاهى

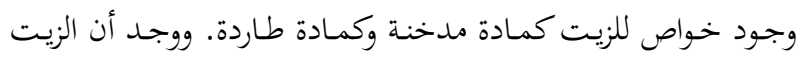

غير سام لبعض النباتات العائله للعنكبوت الأمم ذو البقعتين(القطن -

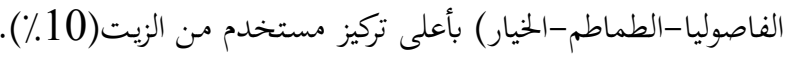

تم التعرف على مكونات الزيت الكيماوية بواسطة استعمال جهاز

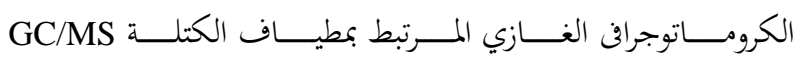

وكانت39.74 ٪ من 8,1- سينيولبالاضافة الى كامفور (22.76

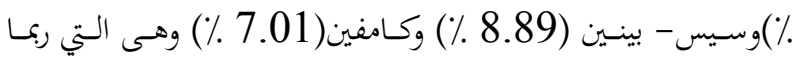

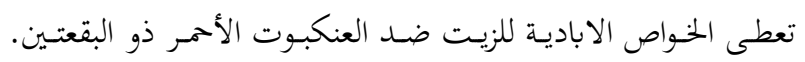

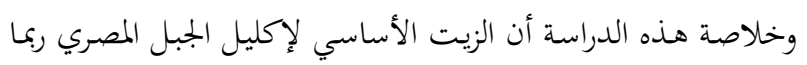

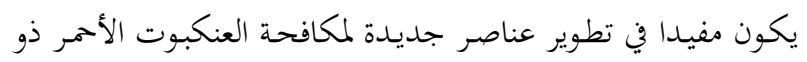

البقعتين.

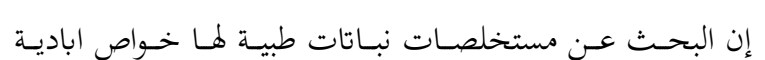

للآنات قد يؤدى إلى اكتشاف عناصر جديدة في مكافحة الآفات. الدراسة الحالية هي محاولة لإيجاد بديلا للمبيدات المصنعة المستخدمة لإندات

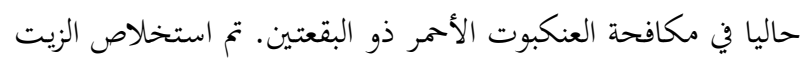

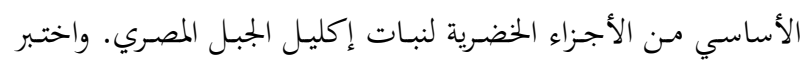

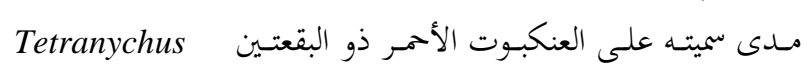
وكذلك العنكبوت المفترس urtica الظروف المعملية. وكانت فترة تعريض الحيوانات للزيت 24، 48،

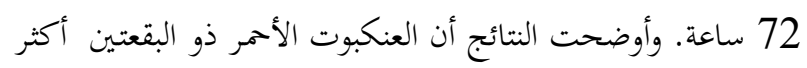

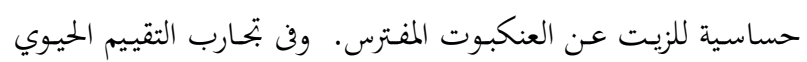

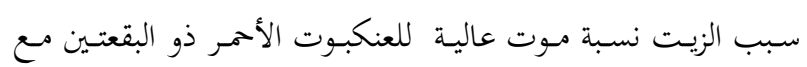

